\title{
Land-Use, Albedo and Air Temperature Changes in the Hula Valley (Israel) during 1946-2008
}

\author{
Moshe Gophen \\ Migal Galilee Scientific Research Institute, Kiryat Shmone, Israel \\ Email: Gophen@Migal.org.il \\ Received 16 July 2014; revised 15 August 2014; accepted 15 September 2014 \\ Copyright (C) 2014 by author and Scientific Research Publishing Inc. \\ This work is licensed under the Creative Commons Attribution International License (CC BY). \\ http://creativecommons.org/licenses/by/4.0/

c) (7) Open Access

\begin{abstract}
Long-Term (1946-2008) record of 35,580 measurements of daily mean air temperatures in three meteorological stations (Dan, Dafna, Kfar Blum) in the Hula Valley, within the drainage basin of Lake Kinneret (Israel) was statistically evaluated. Temperature decline after the drainage of the old Lake Hula and adjacent wetlands (1958) and increase from the mid 1980's, after the implementation of the Hula Project aimed at continuous land green cover were verified. It was suggested that those regional climate changes were due to the change of Albedo levels: lower when land was water covered and higher after regional drainage followed by a decline when vegetation cover became intensive and continuous. Decline of Albedo levels led to higher air temperature and vice versa.
\end{abstract}

\section{Keywords}

Hula, Albedo, Land-Use, Regional Climate

\section{Introduction}

Until 1958 the Hula Valley was covered by the shallow Lake Hula (1.5 m mean depth; 1300 ha water surface), and 4500 ha of which part was permanently and part was seasonally covered by water and vegetation [1]. During 1950-1957 old Lake Hula and the surrounding wetlands were drained and the land use was converted into agricultural development. Nevertheless, about $10 \%$ of the area was inappropriately cultivated causing soil deterioration accompanied by a threat of nutrient flux enhancement into downstream Lake Kinneret. Consequently, a reclamation project (Hula Project (HP)) was implemented during 1990-1997. This project included drainage canals renewal, construction of a wetlands (110 ha), renovation of irrigation method for the agricultural crops 
together with long-term new design of seasonal cycle implementation aimed at continuous green cover.

\subsection{Hydrology}

The Kinneret drainage basin area is $273 \times 10^{3}$ ha, including Hula Valley $\left(20 \times 10^{3}\right.$ ha, altitude range of $60-180$ masl). The altitude of the northern end of the drainage basin is 2814 masl located $61 \mathrm{~km}$ from the south end of the basin at the northern end of Lake Kinneret (WL of $210 \mathrm{mbsl}$ ) creating a mean slope of 5\%. Three major rivers-Hatzbani $\left(130 \times 10^{6} \mathrm{~m}^{3} /\right.$ year), Banyas (app. $115 \times 10^{6} \mathrm{~m}^{3} /$ year), and Dan (app. $260 \times 10^{6} \mathrm{~m}^{3} /$ year) (see Photos 1-2; Map) flow from north to south crossing the Hula Valley. These rivers joint into one river Jordan (app. $500 \times 10^{6} \mathrm{~m}^{3} /$ year) which until 1957 crossed the swampy area through three major arms (tributaries) flowing into old Lake Hula. From the Hula Valley (61 masl) River Jordan flows along $15 \mathrm{~km}$ south into Lake Kinneret $(210 \mathrm{mbsl})$. The water level of old Lake Hula fluctuates between $1.0-2.0 \mathrm{~m}$, inundating the adjacent swamps and land in winter.

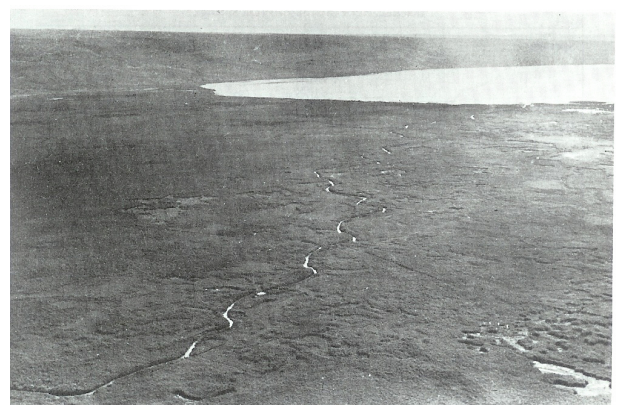

Lake Hula and swamps before drying

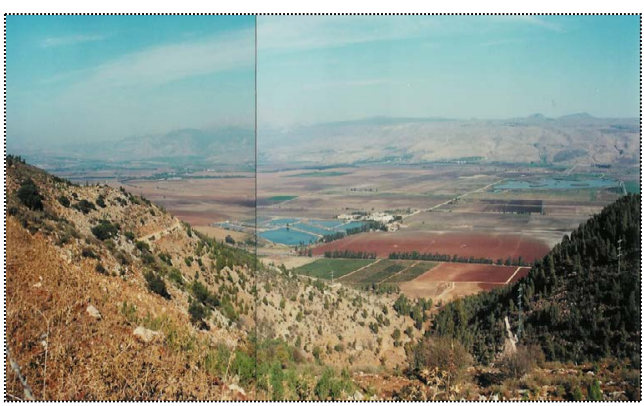

Hula Valley Today

Photo 1

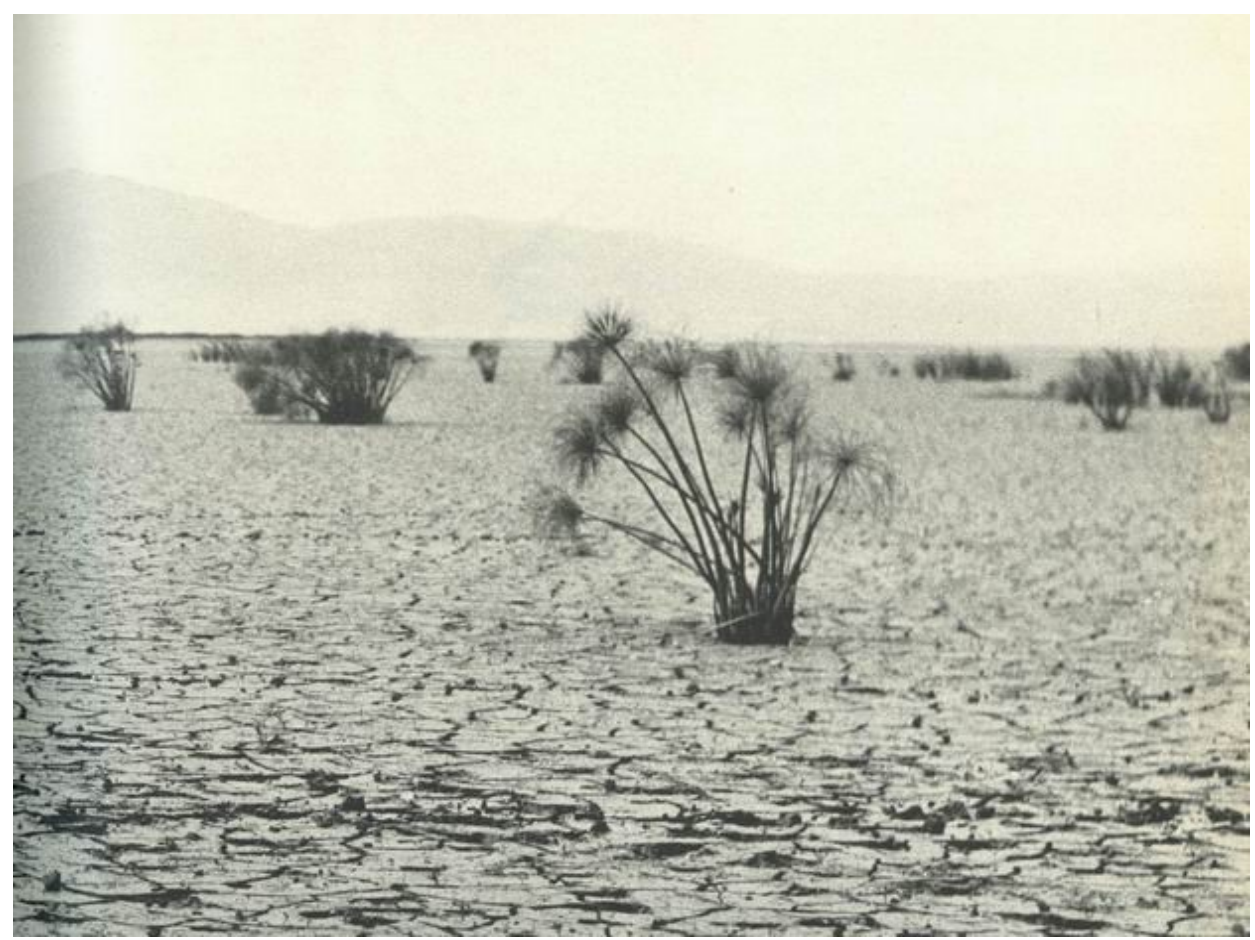

Hula Swamps immediately after drying

Photo 2 


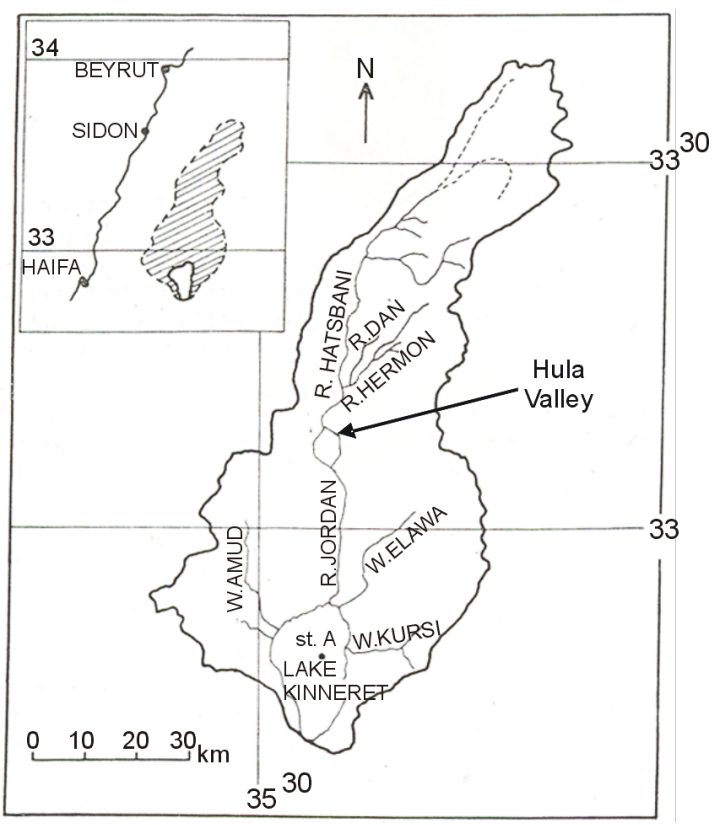

Map of the Kinneret drainage basin

\subsection{The Hula Project (HP)}

During 1950-1957, the old Lake Hula and swampy areas around were drained and 5900 ha of natural ecosystem, including a unique natural composition of fauna and flora, was turned over to agricultural use to serve as an income source for residents in the northern part of Israel. 40 years later the drained area was successfully cultivated not without difficulties. One of those difficulties was bare peat soil which was a source of heavy dust storms. Nevertheless, nutrient flux from the Hula Valley into Lake Kinneret did not really threaten its water quality. As a result of inappropriate management, drainage canals were blocked, soil structure was deteriorated and dehydrated, underground water table declined, outbreaks of underground fires occurred frequently, rodent population outbreak caused severe damage to crops. Ten percent of the drained area, located at the lowest latitude level in the valley was mostly damaged. Therefore, a reclamation project (Hula Project (HP)) was implemented (1990-1997). The project was aimed at the reduction of nutrient fluxes from Hula soil while continuing the economical utilization of the land by partial modification of land-use policy from agriculture to ecotourism. The HP included the creating of wetlands site, "Lake Agmon" (0.6 average depth; 110 ha surface area) to be functioned both as a drainage basin for the entire valley aimed at nutrients removal and eco-touristic site. A plastic sheet (4 mm thickness) was placed vertically $(0-4.5 \mathrm{~m}$ depth) along $2.8 \mathrm{~km}$, across the south-western part of the valley, to prevent underground flows down stream to Lake Kinneret.

As a result of natural modifications and the above description of anthropogenic intervention, the ecological conditions in the Kinneret Ecosystem had undergone several changes: air and lake water temperatures were lowered until the mid 1980's and increased later [2]. The air temperature increase together with WL decline caused enhancement of heat capacity of Lake Kinneret Epilimnion [3]. Regional precipitation was declined during 1970-2010 despite exceptional heavy rain gauge more or less every 10 years [8]. This paper is an attempt aimed at the potential correlation between air temperature and human activity in the Hula Valley through the key factor of Albedo Factor [4]-[7].

\section{Material and Methods}

Temperature data were collected from the Annual Reports of the PalestinelIsrael Meteorological Service (1946-2008) [8]. Air temperature data (35,580 daily measurements) recorded in three stations in the Hula Valley, Dafna, Dan and Kfar Blum located in the vicinity of the swampy region were statistically evaluated. Daily mean temperature was calculated as: (Daily Maximum + Daily Minimum)/2. The following statistical analyses were done. 
STATA 9.1 (2005) [9]:

LOWESS (Tension $=80$ ), Fractional Polynomial and Linear Prediction; ANOVA Test $(p<0.05)$, by Statview 5.0 [10], (SAS Institute Inc.) Power Mac Version.

The information about the Hula Valley, Hula Project, land-use and anthropogenic activities was taken from Hula Project Annual Reports [11] and historical maps collection, Tel Hai College Library.

\section{Results}

Land-use History in the Hula Valley is summarized in Table 1.

Berman [12], Stanhill and Neumann [13] and Serruya [14], published information on Solar Radiation in Lake Kinneret and daily net ranged between $24.3 \times 10^{6} \mathrm{~J} \cdot \mathrm{m}^{-2} \mathrm{~d}^{-1}$ (June-July) and $1.8 \times 10^{6} \mathrm{~J} \cdot \mathrm{m}^{-2} \mathrm{~d}^{-1}$ (December) and annually averaged for the Kinneret region as $15.1 \times 10^{6} \mathrm{~J} \cdot \mathrm{m}^{-2} \mathrm{~d}^{-1}$. It is suggested that anthropogenic changes in the Hula Valley affected air temperatures through Albedo Effect. Therefore, evaluation of Albedo potential impact was investigated. What is Albedo?

If $A=$ Total Incident Energy = Radiation from sun and sky, and B $=$ Energy Reflected from Surface, Then, Albedo is indicated as $\mathbf{N}=$ Net surface Radiation $=\mathbf{A}-\mathbf{B}=$ Albedo in $\%$.

Air temperature changes in the Hula Valley are presented in Figures 1-7 (Fractional Polynomial analyses) and Table 2. The curve in Figure 1 (LOWESS; Tension $=80$ ) represents the entire period 1946-2008, where all measurements are incorporated and indicating a decline from 1946 until the 1980's and increase later. Statistical indicative significance of the conclusions about periodical changes done by Fractional Polynomial analysis with 95\% confidence level is given in Figure 2. The entire record is divided into shorter segments (Figures 3-7) for detailed timing serial changes (Factorial Polynomial). Figure 3 (1946-1958) presents a clear daily temperature decline, the decreasing trend continued during 1959-1970 (Figure 4), and lasted onwards during 1971-1976 (Figure 5). Temperature elevation began in the mid 1980's (Figure 6, 1983-2000) and also shown in the period 1995-2000 (Figure 7). ANOVA $(\mathrm{p}<0.05)$ test (Figure 8) summarized comparison between air temperature fluctuations and periodical changes of land-use changes (Table 1). Air temperatures after the drainage of Lake Hula and the wetlands (1959-1990) were significantly lower than earlier and after HP implementation (1991-2008) increased. The complete record of annual average fluctuations is given in Figure 9. The periodical trends are indicated.

The results presented in Table 2 indicate the following fluctuations: From 1946 to 1990 mean air temperature declined by $1.3^{\circ} \mathrm{C}\left(20.2^{\circ} \mathrm{C}\right.$ to $\left.18.9^{\circ} \mathrm{C}\right)$. Before Hula drainage air temperature was probably higher than during the post drainage period. Nevertheless, later than 1990 (HP implementation was carried out from the early 1990's) air temperature was elevated by $0.9^{\circ} \mathrm{C}$ until 2008. In other words, Hula drainage was followed by decline and HP implementation by increase of air temperature. Results presented in Figure 8 indicate significant air temperature decline after $1958(\mathrm{p}=0.0133)$ which also significantly continued until $1990(\mathrm{p}=0.0023)$. The difference between 1959-1982 and 1983-1990 periods was insignificant. Nevertheless the temperature elevation after 1990 is significant $(\mathrm{p}=0.0261)$.

Table 1. Land use in $10^{2}$ ha (\%) in the Hula Valley during 1949-2010: 1952-1958-Hula drainage; 1990-1994-Hula Project Implementation. Information Source: The Historical Maps Collection; Tel Hai Academic College (Margalit, A. and Israeli, E.).

\begin{tabular}{|c|c|c|c|c|c|}
\hline Year & 1949 & 1958 & 1976 & 1986 & 2010 \\
\hline \multicolumn{6}{|l|}{ Land Use } \\
\hline Water & $14(24 \%)$ & -- & -- & $1(2 \%)$ & $1(2 \%)$ \\
\hline Swamps & $32(54 \%)$ & $4(7 \%)$ & $4(7 \%)$ & $2(3 \%)$ & $4(7 \%)$ \\
\hline Flooded & $13(22 \%)$ & -- & -- & -- & -- \\
\hline Field Crops & -- & $35(59 \%)$ & $46(79 \%)$ & $34(58 \%)$ & $40(68 \%)$ \\
\hline Fishponds & -- & $5(8.5 \%)$ & $5(8 \%)$ & $3(5 \%)$ & $1(2 \%)$ \\
\hline Uncultivated & -- & $10(17 \%)$ & -- & $8(14 \%)$ & $3(5 \%)$ \\
\hline other & -- & $5(8.5 \%)$ & $2(3 \%)$ & $6(10 \%)$ & $4(7 \%)$ \\
\hline Orchards & -- & -- & $2(3 \%)$ & $5(8 \%)$ & $6(9 \%)$ \\
\hline Total & 59 & 59 & 59 & 59 & 59 \\
\hline
\end{tabular}


Table 2. Periodical (see Figure 8) averages of annual means of air temperature in the Hula Valley (three station means).

\begin{tabular}{ccccc}
\hline Period & $\mathrm{n}$ & Mean & SD & SE \\
\hline $1946-1958$ & 13 & 20.2 & 1.3 & 0.4 \\
$1959-1982$ & 24 & 19.4 & 0.9 & 0.2 \\
$1983-1990$ & 8 & 18.9 & 0.4 & 0.2 \\
$1991-2008$ & 18 & 19.8 & 0.6 & 0.1 \\
\hline
\end{tabular}

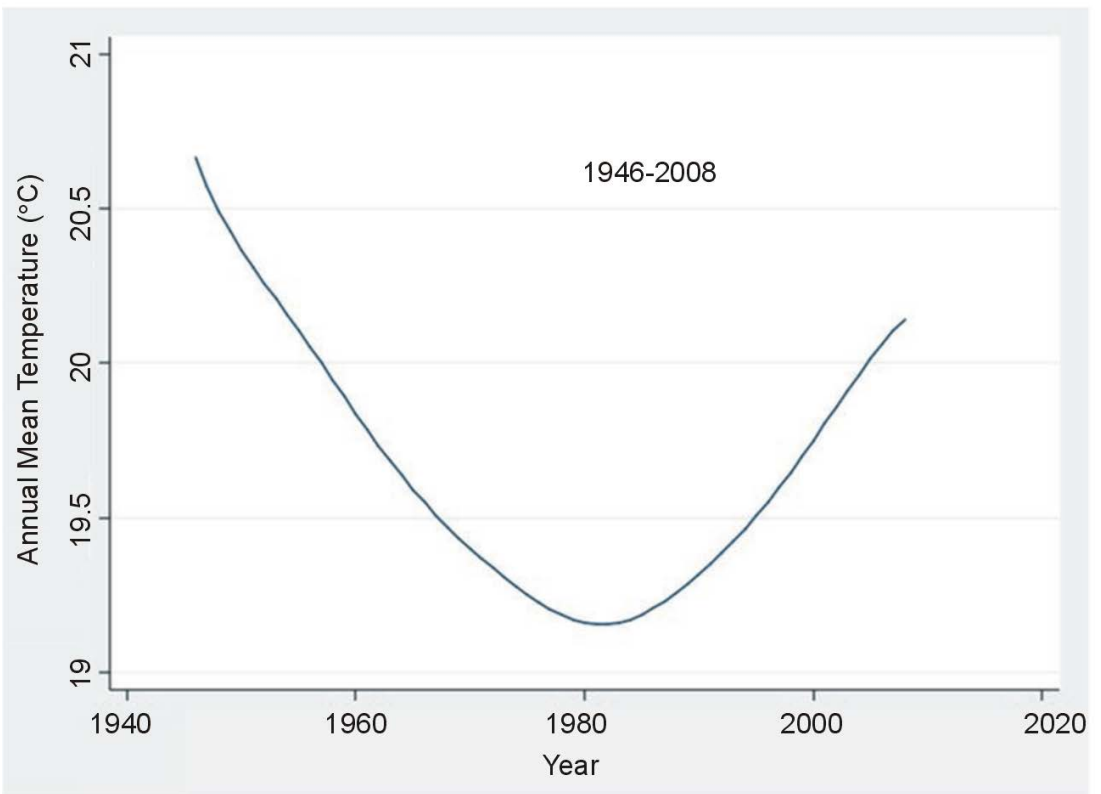

Figure 1. LOWESS $($ Tension $=80)$ curve of annual averages of air temperature daily means during 1946-2008.

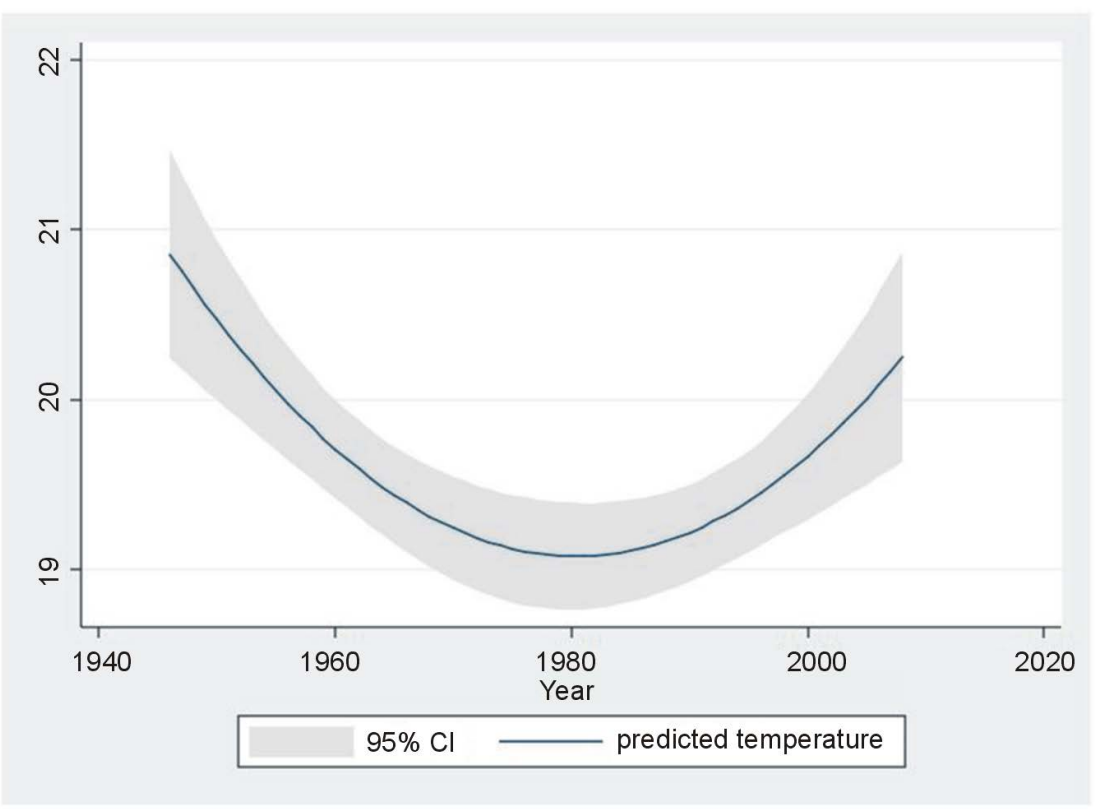

Figure 2. Fractional polynomial curve of annual averages of daily means of air temperatures during 1946-2008. 


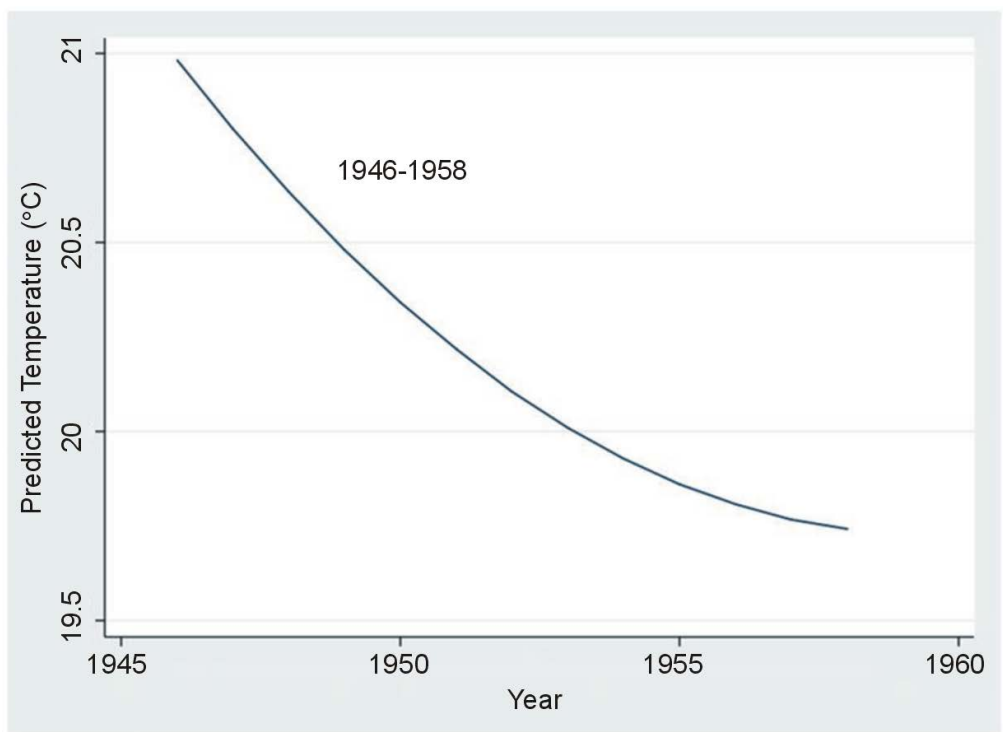

Figure 3. Fractional polynomial curve of annual averages of daily means of air temperatures during 1946-1958.

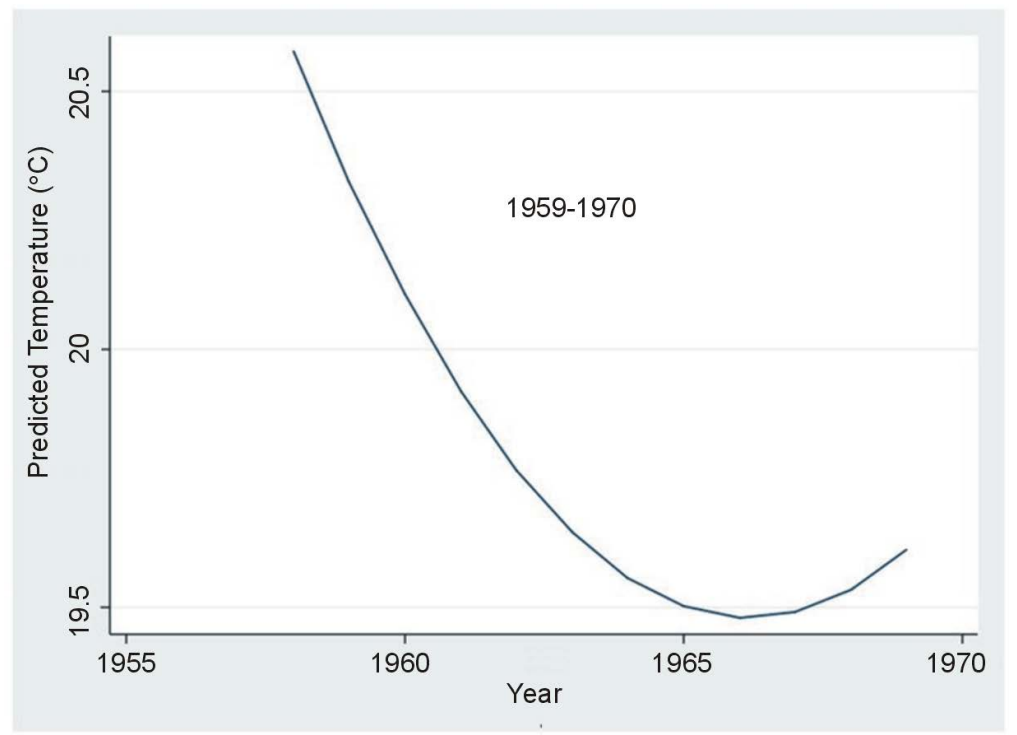

Figure 4. Fractional polynomial curve of annual averages of daily means of air temperatures during 1959-1970.

\section{Discussion}

Hall [7], Hall and Qu [9] and Levis et al. [8] documented the impact of Albedo Feedback on air temperature as scaled for global and continents dimensions. Stanhill [15], and Stanhill and Neumann [13], documented air temperature decline in the Kinneret region but related it to a decline of solar radiation. Changes of Albedo values as scaled globally or regionally were discussed widely in [6] [8] [9], and [16]-[18] [22]. It is suggested that a change of the Albedo value resulted in by the Lake Hula and swamps drainage (1950-1957) was the major reason for the decline of air temperature and agricultural development was later the reason for the increase of air temperature. Data presented in Table 1 indicates the followings: Prior to the Lake Hula and Swamps drainage (1957) $100 \%$ of the valley surface was covered by water and aquatic plants covered app. $50 \%$ of it. When lake and swamps drainage was completed (1958) water covered surface was only $15 \%$ while the rest of it covered seasonally by field crops. During 1959-1986 before the implementation of the Hula Project only $6 \%$ of the sur- 
face was water covered and the rest of it by field crops although 50\% of the time this agricultural land was uncovered. After accomplishment of the Hula Project (presented in 2010 in Table 1) just 11\% of the surface was water covered and the rest of it by field crops but after improvement of periodical development the surface was plant covered most of the time. Albedo reflection from water surface is lower than that from exposed soil surface and higher than that from plant covered land. It is suggested that the Hula drainage operation elevated Albedo reflection accompanied by air temperature decline and temporal continuity of soil green cover (Hula Project operation) lowered Albedo reflection followed by air temperature increase [17].

Albedo is the measure of the reflective of the earth's surface. Water is much more absorbent and less reflective than soil and bare soil is more reflective and less absorbent than grass covered land. When Albedo of certain substrate is increasing heat balance becomes warmer and vice versa [19]-[21]. Consequently, if Albedo increases air temperature above declines. In general, when global light reflection is increasing the mean planet temperature declines. If we take into account the regional scaled case of the Kinneret drainage basin, it is suggested that when the Hula Valley was drained and water cover portion diminished from about $100 \%$ (before 1957) to $15.5 \%$ (after 1957) Albedo was elevated and air temperature declined. During 1958-1986 the Hula Valley land was agriculturally developed with long periods of bare soil surface which was modified later by the Hula Project implementation when land cover was greener most of the time. These sequence of events caused decline of Albedo

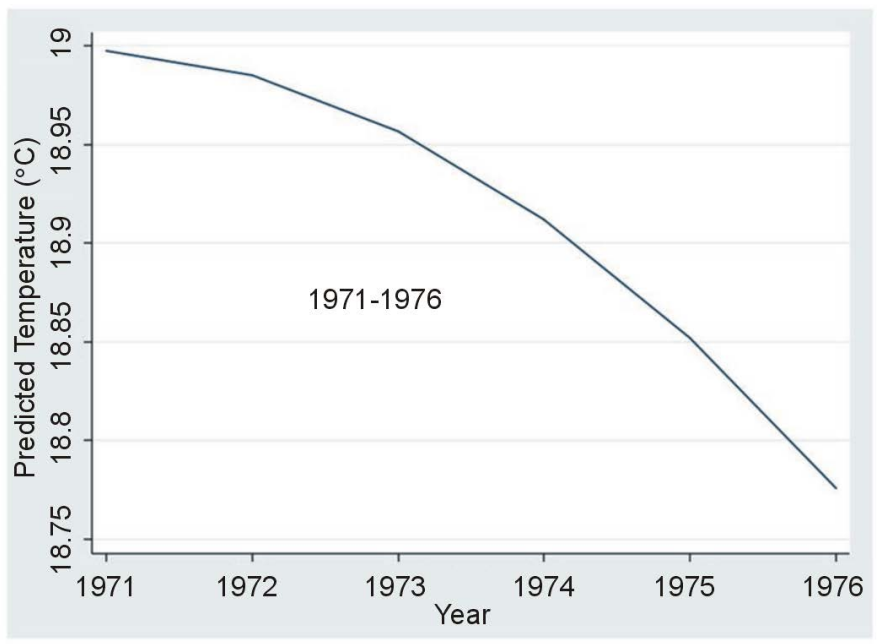

Figure 5. Fractional polynomial curve of annual averages of daily means of air temperatures during 1971-1976.

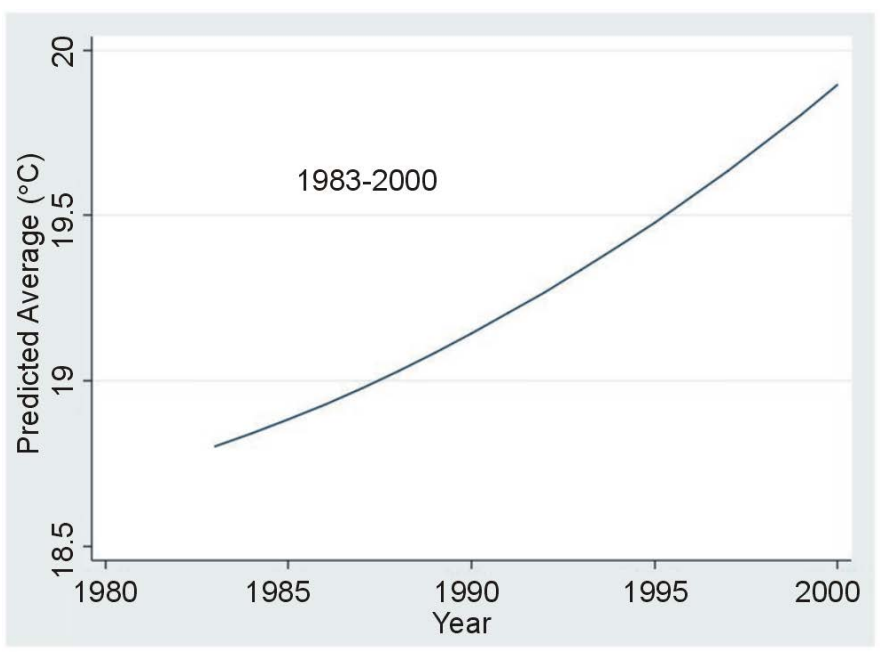

Figure 6. Fractional polynomial curve of annual averages of daily means of air temperatures during 1983-2000. 


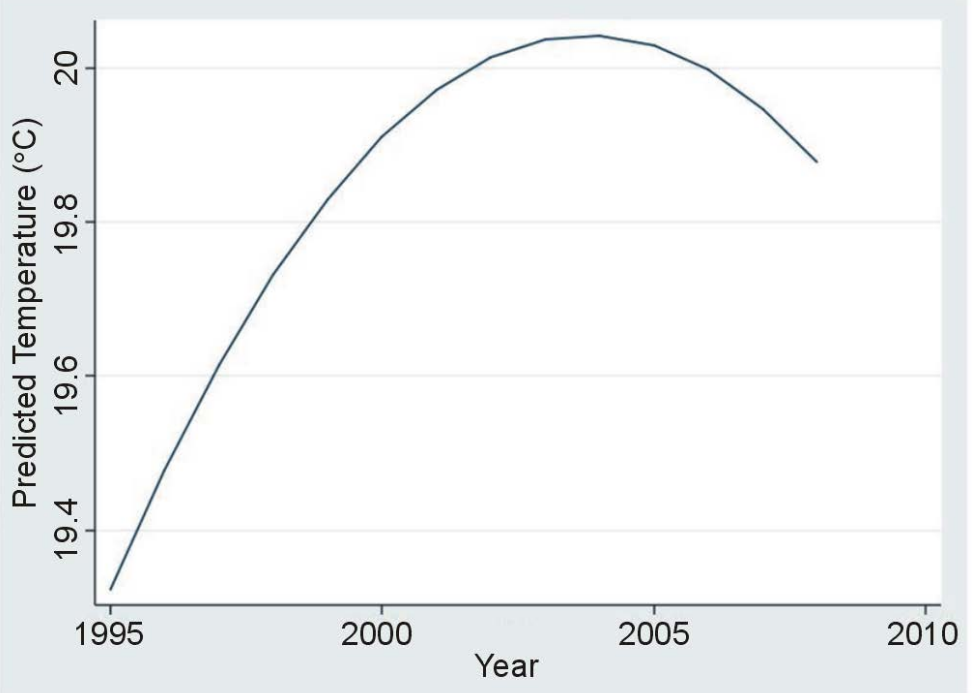

Figure 7. Fractional polynomial curve of annual averages of daily means of air temperatures during 1995-2008.

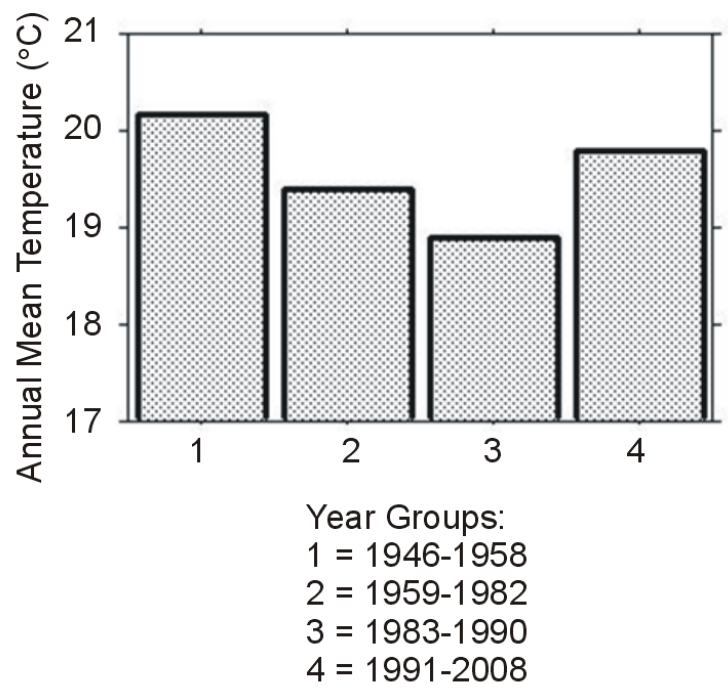

Fisher's PLSD for Temperature $\left({ }^{\circ} \mathrm{C}\right)$

Effect Group

Significance Level: $5 \%$

\begin{tabular}{|c|c|c|c|}
\hline & Mean Diff. & Crit. Diff. & P-Value \\
\hline 1,2 & 0.785 & 0.616 & 0.0133 \\
\hline 1,3 & 1.277 & 0.803 & 0.0023 \\
\hline 1,4 & 0.410 & 0.651 & 0.2121 \\
\hline 2,3 & 0.492 & 0.730 & 0.1828 \\
\hline 2,4 & 0.375 & 0.557 & 0.1834 \\
\hline 3,4 & 0.867 & 0.760 & 0.0261 \\
\hline
\end{tabular}

Figure 8. Results of ANOVA ( $\mathrm{p}<0.05)$ test of comparative periodical (1-4) analysis: $1=1946-1958 ; 2=1959-1982 ; 3=$ 1983-1990; 4 = 1991-2008. 

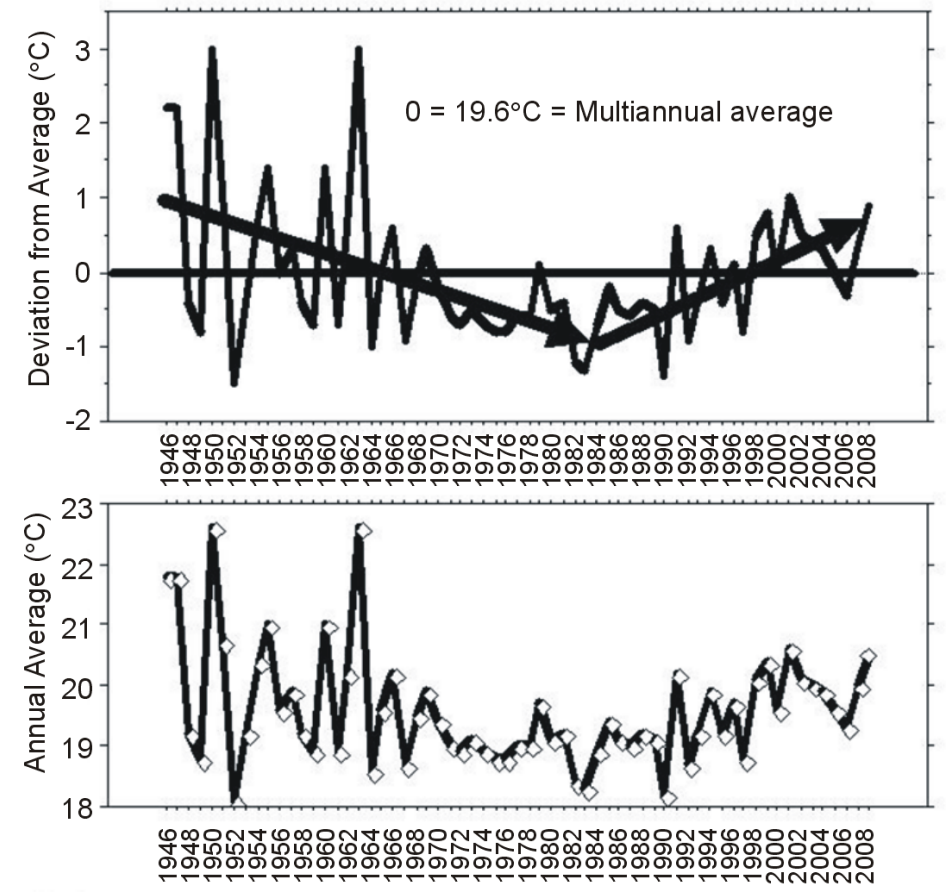

Figure 9. Annual averages of daily mean air temperature (lower panel) and deviation $\left({ }^{\circ} \mathrm{C}\right)$ from the multiannual average $\left(19.6^{\circ} \mathrm{C}\right)$ (upper panel) during 1946-2008; Trends of change are arrowed.

accompanied by air temperature increase. The accomplishment of the Hula Project supplied energetic load resulted by declined Albedo which was transferred to the Evapo-Transpiration latent heat flux followed probably by elevation of air temperature above. The phenomena of higher air temperature above grass land and/or forest in comparison with bare soil surface was widely documented [17] [22]. As much as light reflection from surface (grass land, water covered, forest etc.) is increasing, its temperature is declining and consequently air temperature above it. The history of agro-meteorological events of the Hula Valley includes the following succession: the valley was mostly covered by water and aquatic plants with low value of Albedo. Drainage accomplishment (1957) enhanced reflection (Albedo) and accompanied by decline of air temperature. Aquatic-swampy land use was replaced by agricultural crops with long time uncovered soil surface initiating higher values of Albedo resulted in a decline of air temperature. It was changed by the Hula Project implementation when land use policy was renovated towards longer time of grass (green) cover together with partial water (Agmon Wetlands) cover supporting a decline of Albedo values and elevation of air temperatures. The impact of Hula Project can is indicates as follows: lowering of Albedo values supplied energetic load which was transferred to the latent flux of heat through Evapo-transpiration and the air temperature in air layers covering these land became warmer. During partial bare soil surface after drainage operation and before Hula Project achievement Albedo was elevated and air temperature declined. The dark colored Peat soil in the Hula Valley enhanced this trend of Albedo elevation and air temperature decline. [7] [20] [21] [23]. Documented Albedo values varied between 10\% - 25\% for bare agricultural soil, water 3\% - 5\%, heavy dark soil (Peat) 5\%, moisture soil $15 \%-25 \%$, field crops $15 \%$ $30 \%$, Corn (very common presently in the Hula Valley) $2 \%$ - 4\%. Elevation of Albedo value was accompanied by decline of heat radiation from bare soil. If the mean annual Solar Radiation for the entire Hula Valley (5900 ha) is $15.1 \times 10^{6} \mathrm{~J} / \mathrm{m}^{2} /$ day [12] the total annual radiation load for the entire valley is $32.4 \times 10^{13} \mathrm{~J}$. Before Hula drainage $5 \%$ of it $1.6 \times 10^{13} \mathrm{~J}$ were reflected. After drainage and prior to Hula Project $25 \%\left(8.1 \times 10^{13} \mathrm{~J}\right)$ and $15 \%$ later $\left(4.9 \times 10^{13} \mathrm{~J}\right)$ were reflected. These approximations represent the regional climate changes in the Hula Valley. Similar periodical trends of temperature changes were documented in Lake Kinneret [2]. Rimmer et al. [3] documented these similarities but they concluded that enhancement of heat capacity of the Kinneret Epilimnion is also due to additional contribution of energy absorbance resulted by decline of water level. The decline of Kinneret water level was followed by diminishing of water surface area which lowered total capacity of eva- 
poration induced cooling process, even so heat capacity was enhanced [3]. Although the comprehensive heat balance of the Kinneret Epilimnion was enhanced by water level lowering effect the conclusion presented here that temperature changes in Kinneret were similar to Hula Valley fluctuations are justified. Moreover, decline of Albedo resulted by vegetation cover enhancement cause not only air temperature elevation but also diminishing rainfall as actually was recorded in the Hula Valley [4] [21] [24]. An emphasis of the locality pattern of air temperature changes was also evaluated from long term record of the Jerusalem data [8]. During 1945- 1970 the mean daily temperature in Jerusalem was increased and decreased in the Hula valley. Comparative analysis (ANOVA [p $<0.05]$ Test) has indicated significant $(\mathrm{p}<0.0001)$ lower temperatures in Jerusalem $\left(17.1^{\circ} \mathrm{C}\right)$ than in the Hula Valley $\left(19.9^{\circ} \mathrm{C}\right)$. The regional trait of the climate changes are supported also by Paired $t$-test results that indicated significant $(\mathrm{p}<0.0001)$ dissimilarity between temperature fluctuations in Jerusalem and in the Hula Valley. On the other hand the linkage between Lake Kinneret water level (WL) decline and their temperature probably go partly through the local decline of Albedo level. The elevation of Kinneret Epilimnetic heat budget was suggested by Rimmer [3] to be partly the outcome of WL decline. WL decline caused reduction of solar radiation absorbance as well as reflectance capacities. It is likely that the consequent increase of air temperature is due to the heating to the Kinneret Epilimnion. WL decline accompanied by surface reduction has created two factors of heat enhancement: 1) reduction of cooling effect by smaller capacity of evaporation; 2) lower Albedo level. Those two factors probably enhanced Epilimnetic and consequently air temperatures.

\section{Conclusion}

Long-term record (1946-2008) of daily means of air temperature indicates periodical decline after Hula drainage and increase later when land use is improved. These climatological fluctuations are conclusively related to changes of Albedo levels.

\section{References}

[1] Dimentman, C., Bromley, H.J. and Por, F.D. (1999) Lake Hula. Israeli Academy of Sciences and Humanities, Jerusalem, $170 \mathrm{p}$.

[2] Gophen, M. (2008) Long Term (1970-2001) Eco-Hydrological Processes in Lake Kinneret and Its Watershed. In: Zereini, H., Ed., Climatic Changes and Water Resources in the Middle East and in North Africa, Invited Chapter, Springer, Berlin, 373-402.

[3] Rimmer, A., Gal, G., Opher, T., Lechinsky, Y. and Yacobi, Y.Z. (2011) Mechanisms of Long-Term Variations of the Thermal Structure in a Warm Lake. Limnology and Oceanography, 56, 974-988. http://dx.doi.org/10.4319/10.2011.56.3.0974

[4] Otterman, J. (1974) Baring High Albedo Soils by Overgrazing: A Hypothesized Desertification Mechanism. Science, 186, 531-553. http://dx.doi.org/10.1126/science.186.4163.531

[5] Hall, A. (2004) The Role of Surface Albedo Feedback in Climate. Journal of Climate, 17, 1550-1568. http://dx.doi.org/10.1175/1520-0442(2004)017<1550:TROSAF $>2.0 . C O ; 2$

[6] Levis, S., Bonan, G.B. and Lawrence, P.J. (2007) Present-Day Springtime High-Latitude Surface Albedo as a Predictor of Simulated Climate Sensitivity. Geophysical Research Letters, 34, 12-14.

[7] Hall, A. and Qu, X. (2006) Using the Current Seasonal Cycle to Constrain Snow Albedo Feedback in Future Climate Change. Geophysical Research Letters, 33. http://dx.doi.org/10.1029/2005GL025127

[8] Israel\Palestine (1946-2008) Meteorological Service Annual Reports.

[9] STATA 9.1 (2005) Statistic Data Analysis. Stata Corp., College Station, Texas. Single-User Stata for Macintosh Perpetual license: S.No. 8490533756, Tel Hai.

[10] Statview 5.0 (1998) Power Mac Version. SAS Institute Inc.

[11] Gophen, M., Ed. (1996-2006) Hula Project Annual Reports. KKL and Water Authority and Migal Library.

[12] Berman, T. (1976) Light Penetrance in Lake Kinneret. Hydrobiologia, 49, 41-48. http://dx.doi.org/10.1007/BF00016166

[13] Stanhill, G. and Neumann, J. (1978) Book Chapter: The General Meteorological Background. In: Serruya, C., Ed., Lake Kinneret, Monographiae Biologicae, Junk Publishers, 49-58.

[14] Serruya, S. (1978) Book Chapter: Solar Radiation. In: Serruya, C., Ed., Lake Kinneret, Monographiae Biologicae, Junk Publishers, 59-92.

[15] Stanhill, G. (1992) Lake Kinneret Water Cooling_-Does It due to Solar Radiation Decline? The Biosphere, 22, 8-9. (In 
Hebrew)

[16] Li, Z.Q. and Garand, L. (1994) Estimation of Surface Albedo from Space: A Parameterization for Global Application. Journal of Geophysical Research: Atmospheres, 99, 8335-8350.

[17] Ben-Gai, T., Bitan, A., Manes, A., Alpert, P. and Israeli, A. (1998) Aircraft Measurements of Surface Albedo in Relation to Climate Changes in Southern Israel. Theoretical and Applied Climatology, 61, 207-215.

[18] Otterman, J. and Tucker, C.J. (1985) Satellite Measurements of Surface Albedo and Temperatures in Semi-Desert. Journal of Climate and Applied Meteorology, 24, 228-235. http://dx.doi.org/10.1175/1520-0450(1985)024<0228:SMOSAA>2.0.CO;2

[19] Rotenberg, E. and Yakir, D. (2011) Distinct Patterns of Changes in Surface Energy Budget Associated with Forestation in the Semiarid Region. Global Change Biology, 17, 1536-1548. http://dx.doi.org/10.1111/j.1365-2486.2010.02320.x

[20] Rotenberg, E. and Yakir, D. (2010) Contributions of Semi-Arid Forests to the Climate System. Science, 327, 451-454. http://dx.doi.org/10.1126/science.1179998

[21] Avissar, R. and Verstraete, M. (1990) The Representation of Continental Surface Processes in Atmospheric Models. Reviews of Geophysics, 28, 35-52. http://dx.doi.org/10.1029/RG028i001p00035

[22] Perlin, N. and Alpert, P. (2001) Effects of Land-Use Modification on Potential Increase of Convection-A Numerical Study in South Israel. Journal of Geophysical Research, 106, 22621-22634.

[23] Taha, H. (1997) Urban Climates and Heat Islands: Albedo, Evapotranspiration and Anthropogenic Heat. Energy and Buildings, 25, 99-103.

[24] Charney, J., Quirk, W.J., Chow, S.H. and Kornfield, J. (1977) A Comparative Study of the Effects of Albedo Change on Drought in Semi-Arid Regions. Journal of the Atmospheric Sciences, 34, 1366-1385. http://dx.doi.org/10.1175/1520-0469(1977)034<1366:ACSOTE >2.0.CO;2 
Scientific Research Publishing (SCIRP) is one of the largest Open Access journal publishers. It is currently publishing more than 200 open access, online, peer-reviewed journals covering a wide range of academic disciplines. SCIRP serves the worldwide academic communities and contributes to the progress and application of science with its publication.

Other selected journals from SCIRP are listed as below. Submit your manuscript to us via either submit@scirp.org or Online Submission Portal.
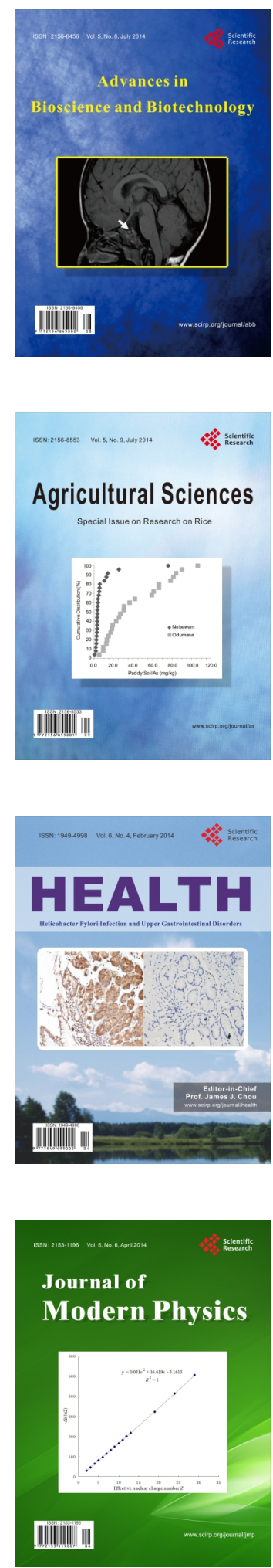
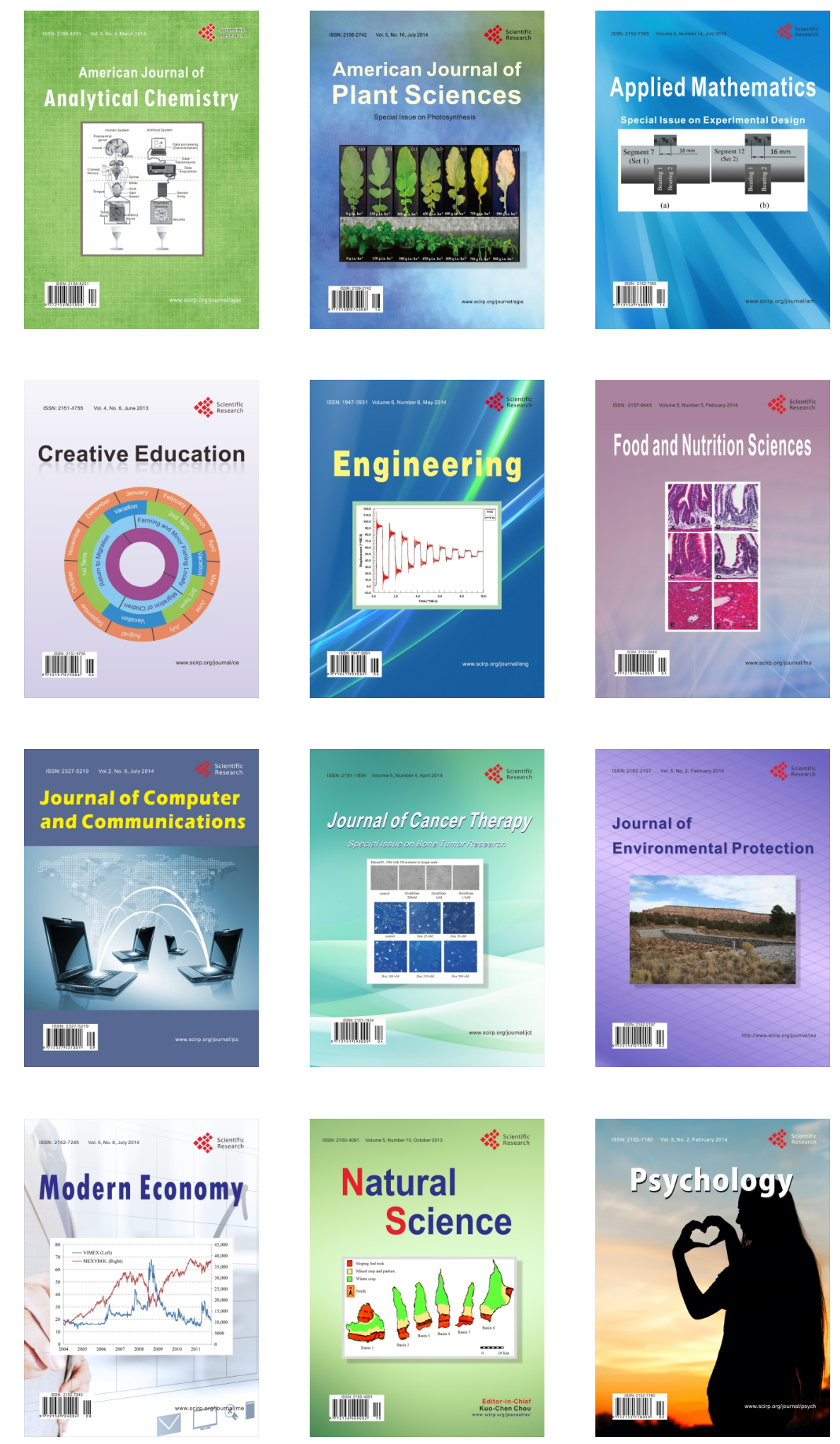